日本結晶学会誌 23, 339 (1981)

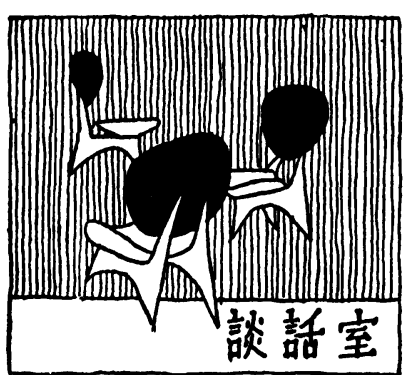

西ドイッでの中性子回折実験

\title{
東大理・鉱物 田贺井 篤平
}

私は1975年 8 月から1980年12月まで，西ドイッの Frankfurt 大学結晶学鉱物学教室で過しました。こ の間, Grenoble の Laue-Langevin 研究所 (ILL) と Karlsruhe の原子核研究所 (KfZ) で, 中性子回 折を用いた鉱物結晶の研究を行ってきましたので，その印象等を少しお話ししましょうと思います。

Karlsruhe の北, 約 $30 \mathrm{~km}$ にある Leopoldhafen といら小さな村の村はずれの森の中に KfZ は，周囲 の世界から隔絶されているかのように, 金網にかこまれて, 存在します。KfZ の警備は厳重を極め, 出 入りには入構証をチェックされ, 時には身分証明書や旅券の提示を要求されます. 警備犬を従えピスト ルを所持した警備員が, パトロールする様子は, 鹿, 狐, 栗鼠, コウノトリ等が, しばしば見られる周 辺の森の静けさとは対照的でした. 私の回折実験は, 研究用原子炉F R 2で行われましたが, ここでは 年 2 回, 西ドイッ全土より, 実験希望者が数十人集って, 前期の測定報告と来期の測定申込みの会議が 開かれます. 回折実験用としては, 5 本の beam line に, 4 台の 4 軸回折計と 4 台の 2 軸回折計が設置 され, 測定期間は, 試料当り $1 \sim 2$ 週間程度が割り当てられます. そして研究成果は, 年 1 回発行され る Ergebnisbericht に掲載される事になっています. 私は, 主としてP 3, P 32, P 110と呼ばれる 3 台 の 4 軸回折計を使いましたが，Cu の平板モノクロメーターで単色化された中性子線は，試料位置で， 約 $6 \times 10^{5} \mathrm{n} / \mathrm{cm}^{2} \mathrm{~s}$ の flux を持ち，通常の鉱物結晶では，5〜10 $\mathrm{mm}^{3}$ の大きさを持っていれば, 1 回 の測定期間内に，例えば，室温と低温といらような 2 組のデータを取る事が出来ました．収集データ は，磁気テープ，または，KfZ の計算センターで，カード化して持ち帰る事になります．ここでも充実 した金工部があり，使用者側の注文に応じた，付属品等の製作に当ってくれます．夜間も，オペレータ 一が巡回して，トラブルの発見や修理，測定の再スタート等の面倒を見てくれます，ただ残念な事に， F R 2は，老朽化したとの理由で, 1981 年春をもって運転を休止し, 測定機器は, Jülich, München, Grenoble 等の原子炉へ移されました. F R 2 の再建設には, 環境問題・予算等もあって, まだまだ糿 余曲折があろらかと思いますが，西独国内での中性子回折に，KfZ が果して来た役割を考えると，より flux の強い原子炬として, 再び登場する事が期待されて扣ります.

ILLについては，今まで本学会誌に，何回か報告がありましたので，簡略に記したいと思いますが， 多くの点で, ドイッ人気質とフランス人気質の差を感じました. ILLは, Grenoble 郊外と言っても, 市中心から車で10分程度の所にあり，市内に原子炬といら感じです，そして，入構する時のチェックの 事実上ない事には驚きました。 まして，雨が降ると，警備員室から出てこない有様です，ILLでは，私 はD 8 と呼ばれる 4 軸回折計を使用しました. 試料位置での flux は $5 \times 10^{7} \mathrm{n} / \mathrm{cm} ・ \mathrm{~s}$ で, $0.3 \sim 1.0 \mathrm{~mm}^{8}$ での結晶で, 充分に良いデータが取れました. ILLには, DECの大型計算機があり. XRAYSYSTEM 等のプログラムが整備されていましたので, 測定データを転送して, 構造解析を, 回折計の横にある端 末で直ちに試みる事が出来ました，ILLでの実験は，仏・独・英の研究機関に所属する者を優先し， 、 シンタイムに余裕があれば，他の国の研究者にも開放する事になっています．毎年かなり多くの実験申 し込みが, 選考委員会で reject されますが,これは, 主として, 意図した実験が, ILL でなければ出 来ないという積極的理由を欠いている事によるようです. KfZ と ILL に共通して厳しかったのは, 健 康管理でした，両研究所とも付属の医療・検査部門を持ち，年 1 ～ 2 回の健康診断を義務付けておりま 
す. 検査は多項目に渡り, 問診, 触診に始って, 身長・体重・視力・聴力の測定, 血液及び尿検査等が 実施されます，これを終えて初めて，線量計を受けとり，Reactor 内に入れる事になります。

話は, 脱線しますが, Jülich, Karlsruhe, München, Grenoble 等, 原子炬のある所, 及びそこへ行く道 には，幸いに(?)、ワイン,ビール、リキュール等々，美酒の名産地が多く，それも楽しみの一つで す.仕事中であっても，食事には，フルコールを欠かさない，お国柄ですので，私も，ずい分良い体験 をいたしました. 予定の実験を終えて Frankfurt へ帰る車のトランクには，いつも相当数のワインが 入っていました。

ILL や KfZ での実験には直接関係ありませんが, 私の所属していた Frankfurt 大学結晶学鉱物学教 室に, 少し触れてみたいと思います. Frankfurt 大学結晶学鉱物学教室は, 1972年まで主任教授であら れた故 O'Daniel 教授の時代から，中性子回折に深い関心を示し，鉱物結晶の中性子回折による研究に 於いて先駆的な仕事をして来ました．＇＇Daniel 教授の後任として，München 大学から是川教授が，主 任教授として就任され，その伝統を受け継ざ，一層発展させてこられました．教室は，戦前の面影を残 した 4 階建の建物で，主任として忙しく研究と事務をこなしておられる是川教授を中心に，教授 4 名， 教育担当助手 2 名, 研究担当助手 5 名のスタッフより成っております. その他, 西ドイッの大学の常と して, 研究者の要望に応じて, 機器の設計・製作に当ってくれる金工室のスタッフ，また写真や化学分 析等を担当する技官が, 教室の研究機能を支えています。そとして, 研究者は, 個性豊かなテーマを時間 にあまり追われる事なく，自らのペースで研究しております．Frankfurt の町自身は，前大戦で灰濜に 帰して，近代的色彩の濃い都市として生れ变ってしまい，ドイッ文化の良い姿を残しているとは決して 言えません，他の近代国家の諸都市の例にもれず，麻薬・青少年非行化等の問題も山積しています，乙 かしながら, 周囲のドイッ人との交流が深まるにつれ, 文化の伝統といらものが, 人間のもっと奥深い 所で脈打っている事を強く感じる事が出来ました.

最後に，西ドイッで研究する機会を与劣をれた，東大鉣物学教室の定永・竹内両教授，Frankfurt 大 学の是川教授, 西独政府の Bundesministerium für Forschung und Technologie 及び Alexander von Humboldt-Stiftung に謝意を表すると共に，5年半の滞独生活を有意義なるのとするために多大な助力 を賜った Frankfurt 大学の Joswig 博士はじめ教室の方々, また, 研究に援助の手をさしのべて下さ った, München 大学の Jagodzinski 教授に，心より御礼を申し上げたいと思います。 